\title{
PDLIM2 Gene
}

National Cancer Institute

\section{Source}

National Cancer Institute. PDLIM2 Gene. NCI Thesaurus. Code C105695.

This gene is involved in the regulation of both cell migration and cell adhesion. 